\title{
Making the smart city: technologies, experiences, and future perspectives
}

\author{
Vladimir Osipov ${ }^{1,2, *}$, Aleksei Zeldner ${ }^{3}$, and Tatiana Skryl ${ }^{4}$ \\ ${ }^{1}$ MGIMO University, 119454, Vernadskogo prospect, 76, Moscow, Russia \\ ${ }^{2}$ Market Economy Institute of the Russian Academy of Sciences, 117418, Nakhimovsky ave., 47, \\ Moscow, Russia \\ ${ }^{3}$ Institute of Economics of the Russian Academy of Sciences, 117418, Nakhimovsky ave., 32, \\ Moscow, Russia \\ ${ }^{4}$ Plekhanov Russian University of Economics, 115038, Stremyanniy pereulok, 36, Moscow, Russia
}

\begin{abstract}
The authors consider the problem of the conceptual the development of "smart cities" in the scholarly literature of foreign and Russian scientists. Based on published literature, the authors classify the concepts of "smart cities" in order to achieve greater clarity of the subject under consideration. Key characteristics of "smart cities" are also considered in the main areas of urban life: energy, water supply, transport, security, services, integration, management.
\end{abstract}

\section{Introduction}

In the scholarly literature on urban policy and economic development there is no single definition of the concept of "smart city", because it includes a huge number of elements depending on the country, discipline, and personal experience of the particular scholar doing his/her research. On the one hand, the city becomes "smart" when it starts to actively use digital technologies in all areas of its economic activities [9]. Information and analytical management of urban development is also a very important component of the concept of "smart city" [4]. And citizens themselves are increasingly using ICT (information \& communication technologies) in their daily activities, making instant communications and receiving information online, with one click. In turn, cities do not lag behind their residents and visitors and also increase the use of ICT, the Internet of things, and robotization in such areas as budget planning, transport, education, healthcare, etc., extracting huge amounts of information and using them qualitatively to improve public life [5].

Thus, the concept of "smart city" implies the development of an urban ecosystem in which the government, businesses, and citizens actively use digital technologies to collect and analyze information, exchange data, etc. in order to create and maintain the effective life of a "smart person" in time and space [2]. We analyze the critical components of the "smart city" in this article, without which one cannot even imagine its construction and effective functioning. In addition, we are considering some technical features of building

\footnotetext{
* Corresponding author: vs.ossipov@gmail.com
} 
"smart cities", as well as review some of the experiences of building "smart cities" in Russia in particular.

\section{What makes a city being "smart"?}

This is not a secret that the development of the concept of "smart city" is a response to (a) outdated forms of management of urban and municipal services and (b) new challenges in urban logistics, security, and ecology. In our opinion, a "smart city" is a new territorial, organizational, and economic solution to the growing problems in the life of modern cities.

As Clunya and Balyuk note, the concept of "smart city" is explored by various branches of science (archeology, sociology, economic science, engineering disciplines), each of which emphasizes its meaning and content of the concept [1]. Drozhzhinov believes that the content of the concept of "smart city" is still in the stage of formation and offers a classification of definitions of the concept of an intelligent city (Table 1) [1].

Table 1. Classification of definitions of the concept of "smart city" according to Drozhzhinov [1].

\begin{tabular}{|l|l|l|l|}
\hline Characteristics & \multicolumn{3}{|c|}{ Classification of concepts } \\
\cline { 2 - 4 } & $\begin{array}{l}\text { The ideological } \\
\text { dimension: what is the } \\
\text { vision of a "smart } \\
\text { city"? }\end{array}$ & $\begin{array}{l}\text { Normative } \\
\text { dimension: } \\
\text { where / what sphere? }\end{array}$ & $\begin{array}{l}\text { Technological / } \\
\text { instrumental } \\
\text { dimension: who will } \\
\text { receive the result of } \\
\text { the "smart city" } \\
\text { project? }\end{array}$ \\
\hline $\begin{array}{l}\text { Purpose of creating a } \\
\text { "smart city" }\end{array}$ & $\begin{array}{l}\text { Improving the quality } \\
\text { of life of residents of } \\
\text { the city }\end{array}$ & $\begin{array}{l}\text { Forming a sustainable } \\
\text { environment for life }\end{array}$ & $\begin{array}{l}\text { Innovative working } \\
\text { life }\end{array}$ \\
\hline Elements & Services & Infrastrucure & Human / social capital \\
\hline
\end{tabular}

We personally believe that a "smart city" is a town-planning concept for the integration of several information and communication technologies and the Internet of things to manage urban processes, including transportation, provision of state and municipal information services, provision of electricity, heat, natural gas, water, provision of educational and medical services, and so on. Actively using information and communication technologies, city authorities and city residents can have instant access to the necessary information, regularly collect data in various areas of urban life, and actively use it to improve the necessary processes. For example, due to the use of sensors that collect and transmit information in real time, the accumulated data can be easily processed and analyzed in order to get knowledge about inefficient processes.

Thus, it is possible to assert that a "smart city" is managed by data, which allows the city authorities to systematically improve the quality of life of the population. The data, as mentioned above, can cover various areas of public life, including security, transportation, medical services, improvement, etc. Video cameras, sensors, information systems, etc. are the main sources of information, which can then be used to better manage the city's life.

Constant monitoring of the main infrastructure facilities (including roads, bridges, tunnels, railways, metro, airports, communication systems, water supply, energy supply, etc.) is carried out in "smart cities" in order to ensure the optimal allocation of resources and security of these facilities [7]. "Smart cities", as a rule, increase the number of services provided to the population regularly and seek to improve their quality. These measures contribute to the formation of a favorable urban environment, contributing to the well-being of citizens, increasing their economic efficiency, and improving their health. In turn, city residents also become one of the main driving forces on the road to transforming their cities 


\section{ICRE 2018}

into "smart" through increasing their participation in the city's life and using information and communication systems [1].

Danakin identifies the three main parts of any "smart city": (a) a smart environment, (b) smart behavior, and (c) smart management [8]. Between these elements, according to Danakin, there is a relationship. First, "smart environment" causes "smart behavior". Second, "smart behavior" forms the concept of "smart environment". Third, smart behavior directly or indirectly determines "smart management". Fourth, smart management contributes to the formation of both "smart environment" and "smart behavior" [8].

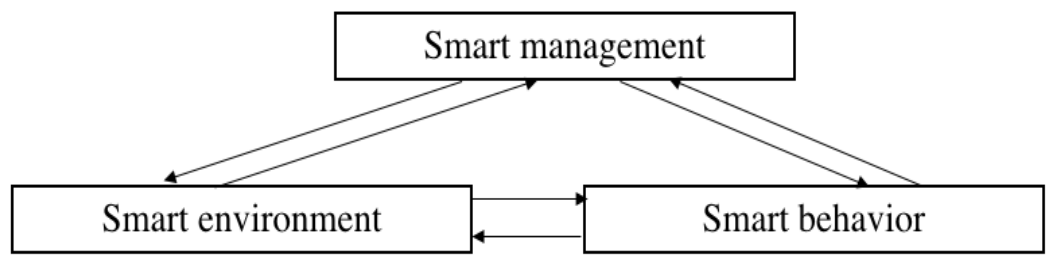

Fig. 1. Interdependence between elements of a "smart city" [8].

Based on the analysis of relevant scientific literature $[2,3,4,5,6]$, it is possible to distinguish the following components of the smart city: energy, water supply, transport, security, services, integration, management, residents (Table 1).

Table 2. Components of the "smart city".

\begin{tabular}{|c|c|c|}
\hline No & Elements & Definitions \\
\hline 1 & Energy & $\begin{array}{l}\text { Automated smart grid and flexible distribution system; } \\
\text { intellectual accounting system and demand management; } \\
\text { integration of renewable energy; energy efficient buildings } \\
\text { and structures. }\end{array}$ \\
\hline 2 & Water supply & $\begin{array}{l}\text { Automated water intake, water distribution, wastewater and } \\
\text { leak detection; regulation of rainwater flow and flood water } \\
\text { in the city; intellectual accounting system and demand } \\
\text { management; software and hardware complex for water } \\
\text { supply management. }\end{array}$ \\
\hline 3 & Transport & $\begin{array}{l}\text { Control of traffic flows and quality of road surface; collection } \\
\text { of payment for the use of roads; infrastructure of charging } \\
\text { stations for electric vehicles; software and hardware for } \\
\text { traffic management and public transport. }\end{array}$ \\
\hline 4 & Security & $\begin{array}{l}\text { Systems of video surveillance, video recording and physical } \\
\text { security of infrastructure facilities; emergency call support } \\
\text { systems; warning system; software and hardware for } \\
\text { managing security systems. }\end{array}$ \\
\hline 5 & Services & E-government, education, health, and tourism. \\
\hline 6 & Integration & $\begin{array}{l}\text { A single information space of a smart city, aggregating } \\
\text { information from objects of urban infrastructure, } \\
\text { management systems and residents. }\end{array}$ \\
\hline 7 & Control & $\begin{array}{l}\text { Systems of decision support, analysis and forecasting, } \\
\text { incident management, provision of state and municipal }\end{array}$ \\
\hline
\end{tabular}




\begin{tabular}{|c|l|l|}
\hline & & services in electronic form, publication of public data. \\
\hline 8 & Residents of the city & $\begin{array}{l}\text { Users of infrastructure and information services; information } \\
\text { providers in the "feedback" mode. }\end{array}$ \\
\hline
\end{tabular}

Based on the study [1], we can identify the basic characteristics and properties that "smart cities" have. First, they combine production activities and infrastructure in a limited area, which is also characteristic of the territorial production complex. Second, "smart cities" strive to achieve the balance, proportionality, and interconnectedness of elements, components, and parts. Third, the presence of a set of territorially localized firms that provide and implement innovative activities aimed at the development and production of innovative products is characteristic of the innovation and industrial cluster, as well as of "smart cities". Fourth, the technological leadership of territorially localized firms and the production of high-tech products is another important element of the "smart city". Fifth, "smart cities" have a special regime for the registration and conduct of economic activities of economic entities.

\section{Russian "smart cities"}

It is worth noting that the transformation of industrial cities into "smart" ones is a worldwide trend that is reflected in the Russian realities. This is a real prospect for Russian cities, especially given the population of the country and the territorial dispersion of many cities. It should be remembered that the development of "smart cities" in Russia should be associated with a radical reform of state and municipal governance.

The National Research Institute of Technology and Communications published a report on the results of the research titled "Indicators of smart cities of NRITC 2017" [7]. Researchers examined 15 cities with the population over one million and the tourist center of Sochi in order to give a clear idea of the directions in which megacities should develop in the development of a "smart city" strategy.

The cities were rated by various indicators, such as the availability of WiFi, the availability of ATMs, Internet booking options, the availability of intelligent surveillance and traffic control systems, etc. As noted on the Institute's website, the top three rankings for 26 indicators included Moscow (the first place), St. Petersburg (second place), and Kazan (third place). By the way, Kazan and the fourth-placed Yekaterinburg are recognized as the most effectively developing cities in terms of budget possibilities. The fifth position has Krasnoyarsk, the sixth place is of in Novosibirsk [7].

However, there are many barriers to the development of "smart cities" in Russia, including: (a) the inability to financially support the introduction of the "smart city" model; (b) the problem of building "smart cities" can be perceived as unimportant and unworthy of attention by city authorities; (c) authorities and businesses may not have a long-term interest in developing innovations and building a "smart city".

\section{Conclusion}

The development of "smart cities" is not a remote perspective but already full-fledged realities of the present. Despite the absence of a single definition of "smart city", a vast experience is accumulated in different parts of the world, including in Russia. Of course, the development of the elements of "smart cities" is very heterogeneous and meets many barriers on its way. However, these processes cannot be stopped or slowed down. 
The reported study was funded by RFBR according to the research project № 16-02-00141.

\section{References}

1. V. L. Klyunya, S. S. Balyuk, Vestnik BGU - Series 3, 3 (2015)

2. D. Sikora-Fernandez, Cities, 78 (2018)

3. B. N. Silva, M. Khan, K. Han, Sustainable Cities and Society, 38 (2018)

4. V. S. Osipov, T. V. Skryl, N. A. Nevskaya, E. V. Shavina, International Business Management, 10, 9 (2016)

5. S. N. Silvestrov, A. G. Zeldner, V. S. Osipov, Mediterranean Journal of Social Sciences, 6, 3 (2015)

6. M. Y. Veselovsky, J. V. Gnezdova, J. A. Romanova, I. V. Kirova, I. I. Idilov, Mediterranean Journal of Social Sciences, 6, 5S2 (2015)

7. National Research Institute of Technology and Communication, Indicators of smart cities of NEITC 2017 (http://niitc.ru/publications/SmartCities.pdf, Moscow, 2017)

8. N. Danakin, Upravleniye Gorodom: Teoriya I Praktika, 2, 9 (2013)

9. T. Yigitcanlar, M. Kamruzzaman, Land Use Policy, 73 (2018) 